\title{
光質がレタス成長と野菜中硝酸イオン濃度に及ぼす影響
}

\author{
松本拓也・伊藤博通・白居祐希・白石斉聖・宇野雄一 \\ 神戸大学農学研究科 657-8501 兵庫県神戸市灘区六甲台町 1-1
}

\section{Effects of Light Quality on Growth and Nitrate Concentration in Lettuce}

\author{
Takuya MATSUMOTO, Hiromichi ITOH, Yuki SHIRAI, Naomasa SHIRAISHI and Yuichi UNO \\ Graduate School of Agricultural Science, Kobe University, 1-1 Rokkodai, Nada-ku, Kobe, 657-8501, Japan
}

\begin{abstract}
The purpose of this research is to clarify the effects of light quality on growth and nitrate concentration of lettuce. The light quality was defined by $\mathrm{R} / \mathrm{B}$ ratio, which was ratio of photon flux density of red light to that of blue one. Lettuces were cultivated in a growth chamber with $12 \mathrm{~h} / 12 \mathrm{~h}$ of light/dark periods under 6 kinds of R/B ratio as follows; 0,1 , $5,10,20$ and $\infty$ (all red). The sum of red and blue photon flux density was kept constant as $230 \mu \mathrm{mol} \mathrm{m} \mathrm{m}^{-2} \mathrm{~s}^{-1}$ at each $\mathrm{R} / \mathrm{B}$ ratio. In the cultivation 3 kinds of air temperature (20, 22 and 25 degrees centigrade) and 3 kinds of cultivation term (1, 2 and 3 weeks) were considered as experimental treatments. After the cultivation fresh weight, percentage dry matter and nitrate concentration were measured. The fresh weight at 5,10 and 20 of R/B ratio was larger than that at other $\mathrm{R} / \mathrm{B}$ ratios and it was found that the larger the percentage dry matter was, the lower the nitrate concentration was. The correlation coefficient between the percentage dry matter and the nitrate concentration became -0.816 . The lowest nitrate concentration and the largest percentage dry matter were realized when the $\mathrm{R} / \mathrm{B}$ ratio was 1 . The results of analysis variance did not show the significant difference among $1,5,10$ of $\mathrm{R} / \mathrm{B}$ ratio in relation to the percentage dry matter or the nitrate concentration. Then it was clarified that the $\mathrm{R} / \mathrm{B}$ ratios of 1,5 and 10 were adequate to realize the rapid growth and the low nitrate concentration.
\end{abstract}

Keywords: LED, lettuce, nitrate concentration, plant factory, $\mathrm{R} / \mathrm{B}$ ratio

\begin{abstract}
緒言
食の安全安心が社会の要請となっている. 硝酸イオンは窒 素同化の初期段階において根から吸収され細胞内へと輸送 される. 自然環境では根圈の硝酸イオン濃度は一般に低く, 能動的に細胞内に運ばれる. しかし水耕栽培が主に採用さ
\end{abstract}

2009 年 12 月 25 日受付

2010 年 5 月 24 日受理

Corresponding author : Hiromichi Itoh (hitoh@kobe-u.ac.jp)
れている植物工場では常に根圈の硝酸イオン濃度が一定に 保たれているので過剩摂取することとなり野菜中硝酸イオン濃 度が高くなりやすい. 人体内に野菜を通して摂取された硝酸 イオンは代謝により亜硝酸イオンへと変化する. 亜硝酸イオン はメトへモグロビン血症や発ガン性物質である N- ニトロソ化 合物の生成の原因になるので, 人体に有害であることがわか

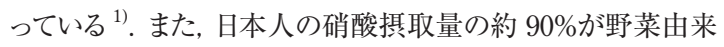
である ${ }^{2)}$. そこで野菜内硝酸イオン濃度の低減に適した栽培 環境の解明が求められている.

現在, 植物工場の光源として主に蛍光灯が使用されてい るが, 新しい光源として LED が注目されている ${ }^{3)}$. LED は小 型, 長寿命, 高輝度であり発光波長を自由に調整できる特性 
がある ${ }^{4,5)}$ ．そこで LED を光源とした植物栽培に関する研究 が数多〈なされてきた. 高辻ら ${ }^{6}$, 森ら ${ }^{7)}$ は LED を用い R/B 比によるサラダナの生育を調查した. 富士原ら ${ }^{8)}$, 大橋ら ${ }^{9,10)}$ は R/B 比によるトマト品質への影響を報告した. 平井ら ${ }^{11)}$ は LED 照明によるナス, リーフレタス, ヒマワリ節間伸長に及ぼ す影響を報告している. このように R/B 比が植物成長に与え る影響は多く研究されてきたが, 光質 $(\mathrm{R} / \mathrm{B}$ 比) が野菜内硝 酸イオン濃度に与える影響は明らかになっていない. そこで, 本研究では光環境に注目し光質 $(\mathrm{R} / \mathrm{B}$ 比) の違いが植物成 長怙よび野菜内硝酸イオン濃度に与える影響の解析を行っ た.

\section{材料および方法}

\section{1. 供試作物}

供試作物としてレタスグリーンウェーブ (Lactuca sativa $\mathrm{L}$., cv. “Greenwave”) を使用した. 育苗はチャンバー (エス ペック (株) BAC-130H, 蛍光灯; National 社製 FL40SS$\mathrm{W} / 37 \mathrm{P})$ 内で行った. このチャンバーは室温, 湿度および照 度の制御が可能である. またエスペック社製 $\mathrm{CO}_{2}$ 制御ユニッ トBAC-NC02 によって二酸化炭素濃度の制御を行った. 栽 培用土には園芸用土であるべルムライトとパーライトを体積比 1 対 1 で混合し, 栽培用セルトレイに敷き詰めた後に播種を行 った. 育苗時の環境設定值は室温 $23^{\circ} \mathrm{C}$, 相対湿度 $60 \%$, 光 量子束密度 $100 \mu \mathrm{mol} \mathrm{m}^{-2} \mathrm{~s}^{-1}$ (LI-COR LI-250 Light Meter および LI-190SB Quantum Sensorにより測定), $\mathrm{CO}_{2}$ 濃度 $400 \mathrm{ppm}$, 明暗周期 $12 \mathrm{~h}$ である. 2 週間育苗後, 活着が良く 4 葉以上に成長している苗を供試苗として使用した. 育苗環 境を Table 1 に示す.

\section{2. 実験方法}

本研究では光質に加え栽培室温 (実験(1) ) および栽培期

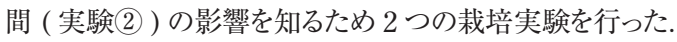

実験(1)では栽培時の室温による影響を解析するため, 各 $\mathrm{R} / \mathrm{B}$ 比試験区において $20^{\circ} \mathrm{C}, 22^{\circ} \mathrm{C}, 25^{\circ} \mathrm{C}$ 々 3 種類の室温区 を用意し, 栽培期間は 2 週間とした.

また実験(2)では栽培期間が植物成長, 硝酸イオン濃度お

Table 1 The environmental condition at raising seedling.

\begin{tabular}{lc}
\hline \hline \multicolumn{1}{c}{ environmental factor } & set value \\
\hline temperature $\left({ }^{\circ} \mathrm{C}\right)$ & 23 \\
humidity $(\%)$ & 60 \\
photon flux density $\left(\mu \mathrm{mol} \mathrm{s}^{-1} \mathrm{~m}^{-2}\right)$ & 100 \\
$\mathrm{CO}_{2}$ density (ppm) & 400 \\
light and dark period (h) & 12 \\
raising seedling term (week) & 2 \\
\hline
\end{tabular}

よび乾物率に与える影響を解析するため, 1, 2, 3 週間の 3 期間設定し, 各期間別々に実験を行った.この 3 期間の室温 は $22^{\circ} \mathrm{C}$ に設定した.

栽培実験は実験(1), 実験(2)共に三洋電機 (株 ) 製チャン バー MIR-553 内で行った. このチャンバーは温度のみ制御 可能である. 光源には LED ( シーシーエス (株) 製光源植 物育成研究用 LED ユニット IS-mini ISL-150X150-RB) を使 用した. 赤色 LED のピーク波長は $660 \mathrm{~nm}$, 青色 LED のピ ーク波長は $470 \mathrm{~nm}$ である. 光質に関する試験区設定として $\mathrm{R} / \mathrm{B}$ 比 (赤色光と青色光の光量子束密度比 ) $0,1,5,10$, 20 および ( 赤色光 $100 \%$ ) の 6 試験区を設けた. 光量は 全試験区で光量子束密度の合計が $230 \mu \mathrm{mol} \mathrm{m}{ }^{-2} \mathrm{~s}^{-1}$ になる ように設定した. 明期 $12 \mathrm{~h}$, 暗期 $12 \mathrm{~h}$ とした. 全ての試験区 においてサンプル数は 6 株である. 水 $1 \mathrm{~L}$ に対し大塚ハウス 1 号を $0.75 \mathrm{~g}$, 大塚ハウス 2 号を $0.50 \mathrm{~g}$ 溶解した養液 (A 処 方標準濃度の $1 / 2)$ を $12 \mathrm{~L}$ 使用した. 養液交換は栽培期間 1 週間ごとに行った. Fig. 1 に栽培装置を示す. 栽培用プレー トに設けた穴に育苗で使用したセルトレイを個々のセルに分割 して挿入し, セルの下部が溶液に浸っている状態で栽培を行 った. また養液は循環していないが, エアーポンプ (( 株) 安 永 LP-30A) によって養液中に常に空気を供給した.

光量子束密度は栽培株頂点で常に一定になるように設定 した. しかし株の成長に伴い株頂点の位置に変化が生じる. そこでジャッキを用いて栽培株頂点から光源までの距離を 2 cm とし, 常に一定に保った. Table 2 に栽培実験における環

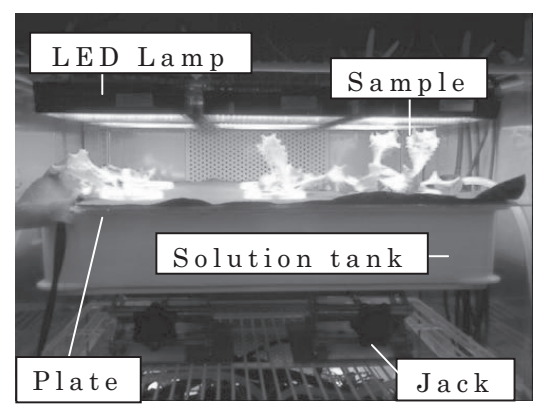

Fig. 1 Picture of cultivation experiment.

Table 2 The environmental condition at cultivation.

\begin{tabular}{lc}
\hline \hline \multicolumn{1}{c}{ environmental factor } & set value \\
\hline temperature $\left({ }^{\circ} \mathrm{C}\right)$ & $20,22,25$ \\
humidity $(\%)$ & 70 \\
photon flux density $\left(\mu \mathrm{mol} \mathrm{s}^{-1} \mathrm{~m}^{-2}\right)$ & 230 \\
$\mathrm{CO}_{2}$ density $(\mathrm{ppm})$ & 350 \\
light and dark period $(\mathrm{h})$ & 12 \\
cultivation term (week) & $1,2,3$ \\
\hline
\end{tabular}


境設定を示す.

栽培期間中は各試験区の温度, 湿度 (共に新栄株式会 社製温湿度変換機 THT-B121にて測定), 養液の EC, pH (( 株) 堀場製作所 D-24 (EC 測定センサ) および D-22 (pH 測定センサ ) を(株) ESD 製グリーンキット 201 並びにデー タロガーソフトウェア DL-400 for Windows を使用し 1 時間毎 に記録した. また毎日同じ時間にレタス各株を定植セルと共に 取り出して (株) AND 社製上皿電子天秤 GF-3000を用い て生体重を測定した.

生体重測定時, チャンバーからサンプルを取り出した直後 にセルから水漏れが生じた. 5 分の放置で確実に水漏れが止 まったことから, チャンバーからサンプルを取り出し 5 分経過後 に生体重の計測を行った.

生体重は地上部, 根圈部およびセル重量を含み, セル中 の用土の含水率が測定毎に異なるので, 定植からちょうど 1 日経過した時点のセルと用土を含んだ重量を基準值とし, 基 準值からの増加重量をレタス生体重増加量とした. 栽培最終 日 (収穫日 ) に野菜内硝酸イオン濃度, 乾物重を測定した.

乾物重を測定するためにエスペック (株) 製熱風乾燥機

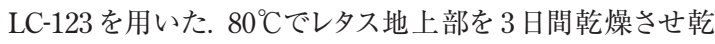
物重を測定した. 乾燥前の生重量で乾物重を除した值を乾 物率として扱った. 乾物率は炭素同化量の目安として扱うこ とができる. 乾燥後のサンプルから硝酸イオンを抽出し東亜 DKK (株) 製イオン分析計 IA-300 により硝酸イオン濃度を測 定した.

\section{2. 解析方法}

\section{各試験区の測定データ間で分散分析を行った. 分散分}

析にはサンプル数が少ないため確率分布の仮定を必要とし ないハンパラメトリック検定によるクラスカル・ウォリス検定を行っ た ${ }^{12)}$. また S 法による多重比較を行った ${ }^{13)}$.

\section{結果および考察}

\section{1.レタスの生体重, 乾物率および硝酸イオン濃度の計測 結果}

それぞれの R/B 比区における生体重増加量の経日変化 を Fig. 2 から Fig. 4 に示す. Fig. 2 のグラフは栽培日数 1 日 から 7 日までは $1,2,3$ 週間区の合計 18 株, 8 日から 14 日ま では 2,3 週間区の合計 12 株, 15 日から 21 日までは 3 週間 区 6 株の測定值の平均值を示す. Fig. 3 および Fig. 4 はそ れぞれ $20^{\circ} \mathrm{C}$ 試験区, $25^{\circ} \mathrm{C}$ 試験区各 6 株の生体重増加量の 平均值推移を示す. 14 日目の生体重増加量に関する分散分 析結果を Table 3 および Table 4 に示す.

Fig. 2, 14 日目までの結果から分かるように, R/B 比の区, 0 区では比較的生体重増加量が小さい. ついで R/B 比 1

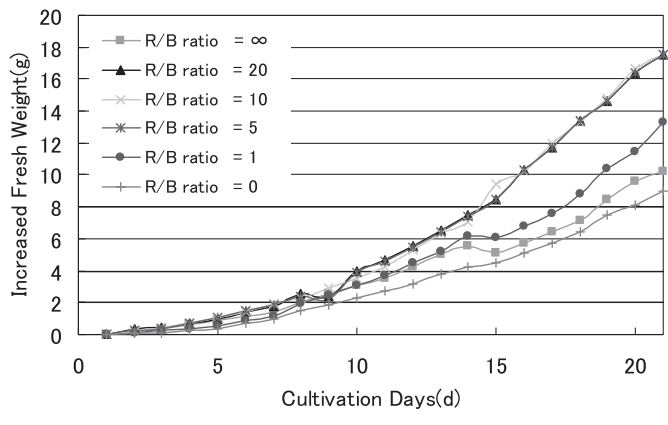

Fig. 2 Time course of the increased fresh weight of lettuces at $22^{\circ} \mathrm{C}$.

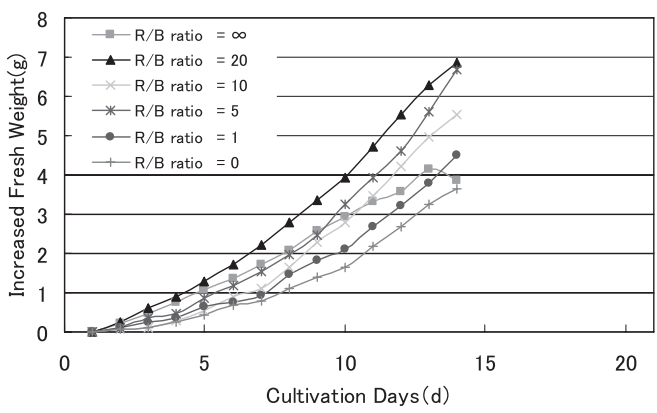

Fig. 3 Time course of the increased fresh weight of lettuces at $20^{\circ} \mathrm{C}$.

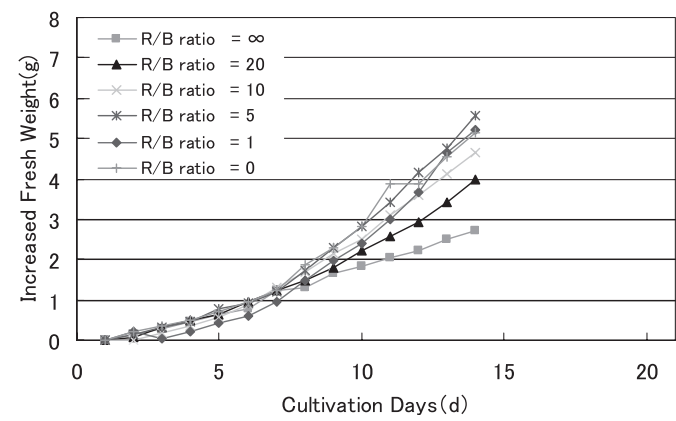

Fig. 4 Time course of the increased fresh weight of lettuces at $25^{\circ} \mathrm{C}$.

Table 3 The examination treatments of $\mathrm{R} / \mathrm{B}$ ratio that showed significant differences as for increased fresh weight in each temperature at 14 th day after transplanting.

\begin{tabular}{ccc}
\hline $\begin{array}{c}\text { Temperature } \\
\text { district }\end{array}$ & $\begin{array}{c}\text { Combinations that showed } \\
\text { signifficant difference }\end{array}$ & $\begin{array}{c}\text { significance } \\
\text { level }\end{array}$ \\
\hline $20^{\circ} \mathrm{C}$ & 20 vs. 0 & $5 \%$ \\
$22^{\circ} \mathrm{C}$ & 20 vs. 0 & $5 \%$ \\
& 5 vs. 0 & $5 \%$ \\
$25^{\circ} \mathrm{C}$ & $\infty$ vs. 5 & $5 \%$ \\
\hline
\end{tabular}


Table 4 The examination treatments of temperature that showed significant differences as for increased fresh weight in each $\mathrm{R} / \mathrm{B}$ ratio at 14th day after transplanting.

\begin{tabular}{ccc}
\hline \hline R/B ratio & $\begin{array}{c}\text { Combinations that showed } \\
\text { signifficant difference }\end{array}$ & $\begin{array}{c}\text { significance } \\
\text { level }\end{array}$ \\
\hline$\infty$ & $22^{\circ} \mathrm{C}$ vs. $25^{\circ} \mathrm{C}$ & $5 \%$ \\
20 & $20^{\circ} \mathrm{C}$ vs. $25^{\circ} \mathrm{C}$ & $5 \%$ \\
& $22^{\circ} \mathrm{C}$ vs. $25^{\circ} \mathrm{C}$ & $1 \%$ \\
\hline
\end{tabular}

区の生体重増加が大きく, R/B 比 20 区, 10 区, 5 区の 3 試 験区では同様な成長曲線を描いており他の 3 試験区よりも大

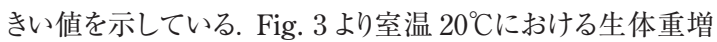
加量の傾向は $22^{\circ} \mathrm{C}$ 区における傾向と似ていることが分かる. しかし Fig. 4 に示す $25^{\circ} \mathrm{C}$ 区では R/B 比 0 が他の室温区に 比べ生体重増加量が大きくなっており, 逆に R/B 比の区では 小さくなっていることが分かる. Table 3 に示した結果からどの 室温区においても R/B 比区間に生体重増加量平均值に有 意差があることが示された. 多重比較により $20^{\circ} \mathrm{C}$ 区および 22 ${ }^{\circ} \mathrm{C}$ 区において $\mathrm{R} / \mathrm{B}$ 比 20 と 0 区間に, さらに $22^{\circ} \mathrm{C}$ 区において は R/B 比 5 区と 0 区間に, また $25^{\circ} \mathrm{C}$ 区において $\mathrm{R} / \mathrm{B}$ 比 区と 5 区の間で有意差が認められた. Table 4 に示された結 果から, R/B 比の区と R/B 比 20 区において室温区の間に 有意差が認められた. これらの結果から赤色光の多い区と少 ない区および温度差のある試験区間で有意差が生じることが 分かる.

LED 光そのものに熱放射は含まれないが LED 基板から の熱放射が存在する. 室温 $25^{\circ} \mathrm{C}$ の設定条件下では LED 基

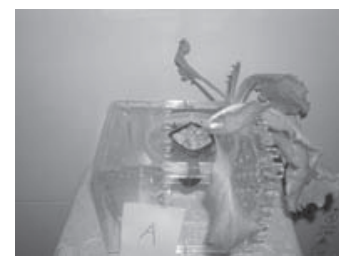

(a)

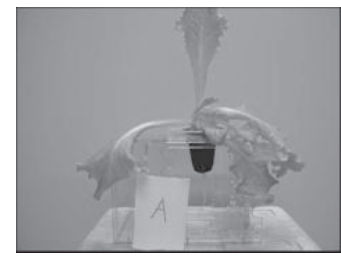

(c)

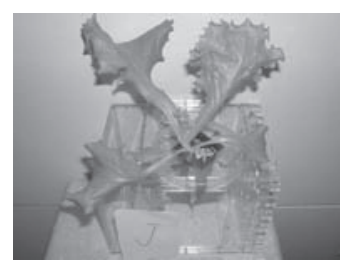

(b)

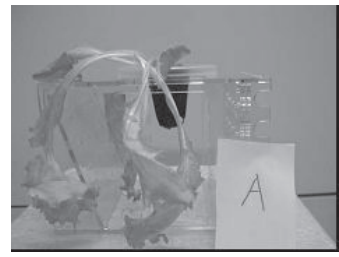

(d)
Fig. 5 Pictures of sample lettuces. ((a)R/B ratio $\infty$ at $22^{\circ} \mathrm{C}$, (b) $\mathrm{R} / \mathrm{B}$ ratio 0 at $22^{\circ} \mathrm{C}$, (c) $\mathrm{R} / \mathrm{B}$ ratio $\infty$ at $20^{\circ} \mathrm{C},(\mathrm{d}) \mathrm{R} / \mathrm{B}$ ratio $\infty$ at $25^{\circ} \mathrm{C}$ )

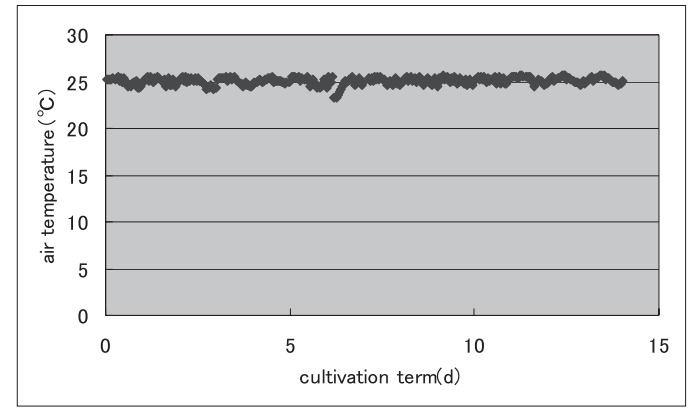

Fig. 6 Time course of measured air temperature at 25 ${ }^{\circ} \mathrm{C}$ condition.

板からの熱放射により葉面付近の気温が栽培適正温度の上

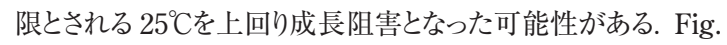
5 に示した写真 (a) (c) (d) からも高温障害の影響がみられ た. また Fig. 6 にチャンバー内室温推移図を示す. また温湿 度センサはチャンバー内上部に設置した. 気温は制御できて いたが葉温が高くなっていたと考えられる.

次に全栽培期間と温度区における乾物率の測定結果を Fig. 7 および Fig. 8 に示す. 図中のエラーバーは標準偏差を 示している. また乾物率についての分散分析の結果を Table

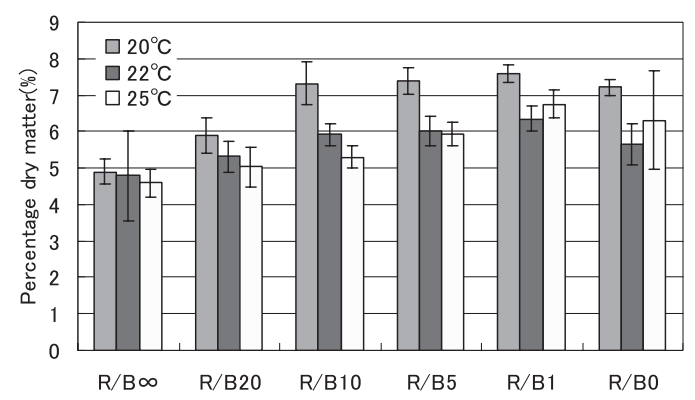

Fig. 7 Mean value of percentage dry matter at each $\mathrm{R} / \mathrm{B}$ ratio with relation to the air temperature at 14th day after transplanting.

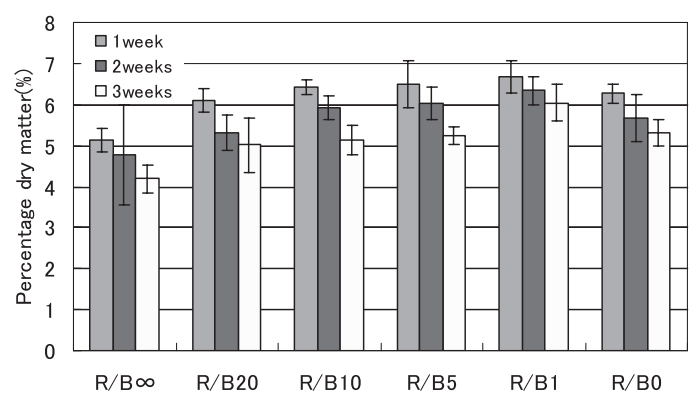

Fig. 8 Mean value of percentage dry matter at each $\mathrm{R} / \mathrm{B}$ ratio with relation to the cultivation term at $22^{\circ} \mathrm{C}$. 
Table 5 The examination treatments of $\mathrm{R} / \mathrm{B}$ ratio that showed significant differences as for percentage dry matter in each temperature at 14 th day after transplanting.

\begin{tabular}{ccc}
\hline \hline $\begin{array}{c}\text { Temperature } \\
\text { district }\end{array}$ & $\begin{array}{c}\text { Combinations that showed } \\
\text { signifficant difference }\end{array}$ & $\begin{array}{c}\text { significance } \\
\text { level }\end{array}$ \\
\hline $20^{\circ} \mathrm{C}$ & $\infty$ vs. 10 & $5 \%$ \\
& $\infty$ vs. 5 & $5 \%$ \\
& $\infty$ vs. 1 & $1 \%$ \\
$22^{\circ} \mathrm{C}$ & $\infty$ vs. 1 & $5 \%$ \\
$25^{\circ} \mathrm{C}$ & $\infty$ vs. 1 & $1 \%$ \\
\hline
\end{tabular}

Table 6 The examination treatments of $\mathrm{R} / \mathrm{B}$ ratio that showed significant differences as for percentage dry matter in each cultivation term at $22^{\circ} \mathrm{C}$.

\begin{tabular}{ccc}
\hline \hline $\begin{array}{c}\text { Cultivation } \\
\text { term }\end{array}$ & $\begin{array}{c}\text { Combinations that showed } \\
\text { signifficant difference }\end{array}$ & $\begin{array}{c}\text { significance } \\
\text { level }\end{array}$ \\
\hline 1 week & $\infty$ vs. 1 & $1 \%$ \\
2 weeks & $\infty$ vs. 1 & $5 \%$ \\
3 weeks & $\infty$ vs. 1 & $1 \%$ \\
\hline
\end{tabular}

Table 7 The examination treatments of tempertures that showed significant differences as for percentage dry matter in each $\mathrm{R} / \mathrm{B}$ ratio at 14th day after transplanting.

\begin{tabular}{ccc}
\hline \hline R/B ratio & $\begin{array}{c}\text { Combinations that showed } \\
\text { signifficant difference }\end{array}$ & $\begin{array}{c}\text { significance } \\
\text { level }\end{array}$ \\
\hline 10 & $20^{\circ} \mathrm{C}$ vs. $25^{\circ} \mathrm{C}$ & $1 \%$ \\
5 & $20^{\circ} \mathrm{C}$ vs. $22^{\circ} \mathrm{C}$ & $5 \%$ \\
& $20^{\circ} \mathrm{C}$ vs. $25^{\circ} \mathrm{C}$ & $1 \%$ \\
1 & $20^{\circ} \mathrm{C}$ vs. $22^{\circ} \mathrm{C}$ & $1 \%$ \\
0 & $20^{\circ} \mathrm{C}$ vs. $22^{\circ} \mathrm{C}$ & $5 \%$ \\
\hline
\end{tabular}

Table 8 The examination treatments of cultivation term that showed significant differences as for percentage dry matter in each $\mathrm{R} / \mathrm{B}$ ratio at $22^{\circ} \mathrm{C}$.

\begin{tabular}{ccc}
\hline \hline R/B ratio & $\begin{array}{c}\text { Combinations that showed } \\
\text { signifficant difference }\end{array}$ & $\begin{array}{c}\text { significance } \\
\text { level }\end{array}$ \\
\hline$\infty$ & 1week vs. 3weeks & $5 \%$ \\
20 & 1week vs. 3weeks & $5 \%$ \\
10 & 1week vs. 3weeks & $1 \%$ \\
5 & 1week vs. 3weeks & $1 \%$ \\
1 & 1week vs. 3weeks & $5 \%$ \\
0 & 1week vs. 3weeks & $5 \%$ \\
\hline
\end{tabular}

5 から Table 8 に示す. 室温区間の分散分析には 14 日目 (栽培期間 2 週間区収穫) 時の乾物率を, 栽培期間区間の 分散分析には室温 $22^{\circ} \mathrm{C}$ 区の乾物率を使用した.
栽培期間ごとの乾物率を比較すると 3 週間区, 2 週間区, 1 週間区の順に乾物率が大きくなり, 栽培期間が長くなるほど 乾物率が小さくなる傾向がみられた.

また室温ごとの乾物率を比較すると赤色光が多く含まれる 試験区 $(\mathrm{R} / \mathrm{B}$ 比 $20,10,5)$ では $20^{\circ} \mathrm{C}$ 区, $22^{\circ} \mathrm{C}$ 区, $25^{\circ} \mathrm{C}$ 区 の順に乾物率が大きくなり, 青色光の比率が大きい試験区 (R/B 比 1) では $20^{\circ} \mathrm{C}$ 区, $25^{\circ} \mathrm{C}$ 区, $22^{\circ} \mathrm{C}$ 区の順に乾物率が大 きくなる傾向がみられた.

$\mathrm{R} / \mathrm{B}$ 比ごとの乾物率を比較すると, 全ての栽培室温, 栽 培期間で $\mathrm{R} / \mathrm{B}$ 比 $\infty$ 区から青色光の割合が増加するにつれ 乾物率は徐々に増加する傾向がみられた. しかし赤色光を含 まない $\mathrm{R} / \mathrm{B}$ 比 0 区では $\mathrm{R} / \mathrm{B}$ 比 1 と比較し乾物率が低下す る傾向がみられた。

Table 5 と Table 6 の結果から, 温度別あるいは栽培期間 別に考えた場合に赤色の多い試験区と青色の多い試験区と の間に乾物率の差が生じていることが明らかになった. Table 7 と Table 8 より, R/B 比別に考えた場合は, $20^{\circ} \mathrm{C}$ 区と $25^{\circ} \mathrm{C}$ 区 の間および 1 週間区と 3 週間区との間に乾物率の差が生じ ていることがわかった。

次に全栽培期間と温度区における硝酸イオン濃度の測定

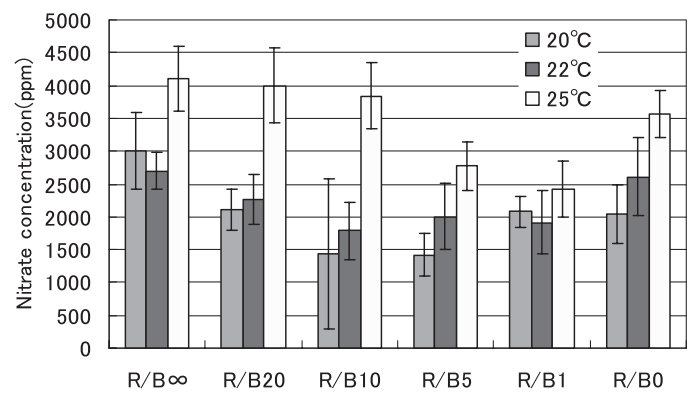

Fig. 9 Mean value of nitrate concentration at each $\mathrm{R} / \mathrm{B}$ ratio with relation to the air temperature at 14th day after transplanting.

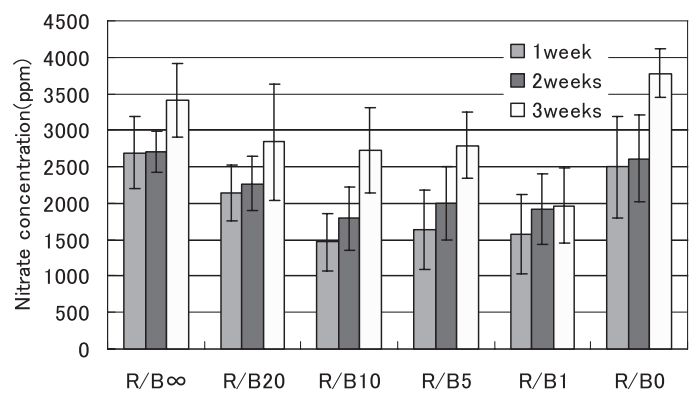

Fig. 10 Mean value of nitrate concentration at each $\mathrm{R} / \mathrm{B}$ ratio with relation to the cultivation term at $22^{\circ} \mathrm{C}$. 
Table 9 The examination treatments of $\mathrm{R} / \mathrm{B}$ ratio showed significant differences as for nitrate concentration in each temperature at 14th day after transplanting.

\begin{tabular}{ccc}
\hline \hline $\begin{array}{c}\text { Temperature } \\
\text { district }\end{array}$ & $\begin{array}{c}\text { Combinations that showed } \\
\text { signifficant difference }\end{array}$ & $\begin{array}{c}\text { significance } \\
\text { level }\end{array}$ \\
\hline $20^{\circ} \mathrm{C}$ & $\infty$ vs. 10 & $5 \%$ \\
& $\infty$ vs. 5 & $5 \%$ \\
$25^{\circ} \mathrm{C}$ & $\infty$ vs. 1 & $5 \%$ \\
& 20 vs. 1 & $5 \%$ \\
\hline
\end{tabular}

Table 10 The examination treatments of temperatures showed significant differences as for nitrate concentration in each $\mathrm{R} / \mathrm{B}$ ratio at 14 th day after transplanting.

\begin{tabular}{ccc}
\hline \hline R/B ratio & $\begin{array}{c}\text { Combinations that showed } \\
\text { signifficant difference }\end{array}$ & $\begin{array}{c}\text { significance } \\
\text { level }\end{array}$ \\
\hline$\infty$ & $22^{\circ} \mathrm{C}$ vs. $25^{\circ} \mathrm{C}$ & $1 \%$ \\
20 & $20^{\circ} \mathrm{C}$ vs. $25^{\circ} \mathrm{C}$ & $1 \%$ \\
& $22^{\circ} \mathrm{C}$ vs. $25^{\circ} \mathrm{C}$ & $5 \%$ \\
10 & $20^{\circ} \mathrm{C}$ vs. $25^{\circ} \mathrm{C}$ & $1 \%$ \\
5 & $20^{\circ} \mathrm{C}$ vs. $25^{\circ} \mathrm{C}$ & $1 \%$ \\
0 & $20^{\circ} \mathrm{C}$ vs. $25^{\circ} \mathrm{C}$ & $1 \%$ \\
\hline
\end{tabular}

Table 11 The examination treatments of cultivation term showed significant differences as for nitrate concentration in each $\mathrm{R} / \mathrm{B}$ ratio at $22^{\circ} \mathrm{C}$.

\begin{tabular}{ccc}
\hline \hline R/B ratio & $\begin{array}{c}\text { Combinations that showed } \\
\text { signifficant difference }\end{array}$ & $\begin{array}{c}\text { significance } \\
\text { level }\end{array}$ \\
\hline 10 & 1week vs. 3weeks & $5 \%$ \\
5 & 1week vs. 3weeks & $5 \%$ \\
0 & 1week vs. 3weeks & $5 \%$ \\
& 2weeks vs. 3weeks & $5 \%$ \\
\hline
\end{tabular}

Table 12 The examination treatments of $\mathrm{R} / \mathrm{B}$ ratio showed significant differences as for nitrate concentration in each cultivation term at $22^{\circ} \mathrm{C}$.

\begin{tabular}{ccc}
\hline \hline $\begin{array}{c}\text { Cultivation } \\
\text { term }\end{array}$ & $\begin{array}{c}\text { Combinations that showed } \\
\text { signifficant difference }\end{array}$ & $\begin{array}{c}\text { significance } \\
\text { level }\end{array}$ \\
\hline 3weeks & 1 vs. 0 & $1 \%$ \\
\hline
\end{tabular}

值を Fig. 9 および Fig. 10 に示す. また硝酸イオン濃度につい ての分散分析結果を Table 9 から Table 12 に示す.

室温区間の分散分析には 14 日目 (栽培期間 2 週間区収 穫 ) 時の硝酸イオン濃度を, 栽培期間区間の分散分析には 室温 $22^{\circ} \mathrm{C}$ 区の硝酸イオン濃度を使用した.

Fig. 9 より室温によって硝酸イオン濃度を比較するとほとん どの $\mathrm{R} / \mathrm{B}$ 比区で $25^{\circ} \mathrm{C}$ 区, $22^{\circ} \mathrm{C}$ 区, $20^{\circ} \mathrm{C}$ 区の順で高濃度とな
った. の区および 1 区で $25^{\circ} \mathrm{C}$ 区, $20^{\circ} \mathrm{C}$ 区, $22^{\circ} \mathrm{C}$ 区の順に高 濃度であった。

Fig. 10 より栽培期間ごとの硝酸イオン濃度を比較すると 3 週間区, 2 週間区, 1 週間区の順に高濃度となり, 栽培期間 が長くなるほど硝酸イオン濃度が高くなる傾向がみられた.

$\mathrm{R} / \mathrm{B}$ 比ごとの硝酸イオン濃度を比較すると, R/B 比 $\infty$, $\mathrm{R} / \mathrm{B}$ 比 0 区が他の光質と比較し硝酸イオン濃度が高い傾向 を示した. また R/B 比 10 区, R/B 比 5 区, R/B 比 1 区は 他の試験区と比較して硝酸イオン濃度が低い傾向であった。

Table 9 から Table 12 より赤色の多い試験区と青色の多 い試験区との間に硝酸イオン濃度の差が生じていることが明 らかになった. また, 1 週間区と 3 週間区との間に硝酸イオン 濃度に差が生じていることがわかった。

\section{2. 乾物率と硝酸イオン濃度の関係}

Fig. 7 から Fig. 10 に示した結果から乾物率が大きい試験 区では硝酸イオン濃度が低く, 逆に乾物率が小さい試験区で は硝酸イオン濃度が高い傾向がみられた. Table 13 に各試 験区の乾物率と硝酸イオン濃度の相関係数を示す. Table 13 には全試験区における相関係数と各温度区別の相関係数を 示す. また Fig. $11 に 1,2,3$ 週間区各 R/B 比区の乾物率 と硝酸イオン濃度の分布を表す.

栽培期間ごとの乾物率と硝酸イオン濃度との相関係数は, $20^{\circ} \mathrm{C}$ 区で $-0.820,22^{\circ} \mathrm{C}$ 区で $-0.816,25^{\circ} \mathrm{C}$ 区で -0.850 , また この 3 試験区全体で -0.710 となり負の相関がみられた. ここ から乾物率と硝酸イオン濃度には相関があると考えられる.

Fig. 2 から Fig. 4 に示したように $25^{\circ} \mathrm{C}$ 区の生体重増加量 は $20^{\circ} \mathrm{C}$ 区および $22^{\circ} \mathrm{C}$ 区より 小さくなっている. $25^{\circ} \mathrm{C}$ 区では上 述のように LED 基板からの熱放射により葉面周囲の気温が レタス栽培の適温を上回っていたと考えられる.このことから $25^{\circ} \mathrm{C}$ 区では $20^{\circ} \mathrm{C}$ 区および $22^{\circ} \mathrm{C}$ 区に比べて成長が困難な環 境にあったため, 乾物率と硝酸イオン濃度に与える R/B 比の 影響が $20^{\circ} \mathrm{C}$ 区, $22^{\circ} \mathrm{C}$ 区よりも顕著に表れたと考えられる. その 結果として $25^{\circ} \mathrm{C}$ 区の相関係数絶対值は $20^{\circ} \mathrm{C}$ 区および $22^{\circ} \mathrm{C}$ 区よりも大きくなったと考えられる.

また, $20^{\circ} \mathrm{C}$ 区 $22^{\circ} \mathrm{C}$ 区の比較では Table 7 より乾物率で 有意差を示している R/B 比が存在するが, Table 10 に示し たように硝酸イオン濃度に有意差は見られなかった. このこと

Table 13 The correlation coefficient between percentage dry matter and nitrate concentration of experimental treatments.

\begin{tabular}{cc}
\hline \hline Experrimental treatment & Correlation coefficient \\
\hline All experrimental treatment & -0.710 \\
$20^{\circ} \mathrm{C}$ 2weeks & -0.820 \\
$22^{\circ} \mathrm{C} 1-2-3$ weeks & -0.816 \\
$25^{\circ} \mathrm{C}$ 2weeks & -0.850 \\
\hline
\end{tabular}




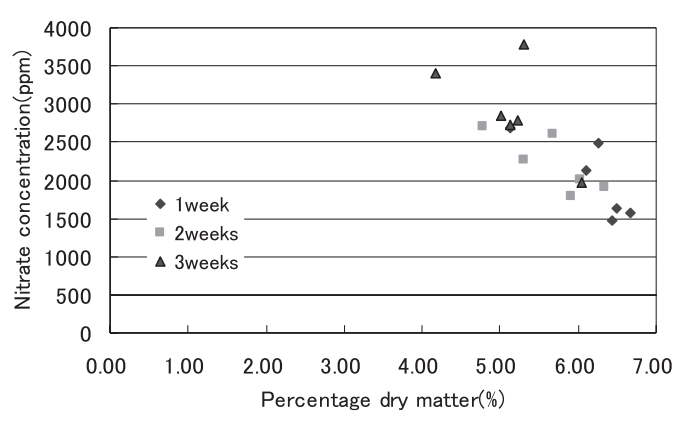

Fig. 11 Relation between percentage dry matter and nitrate concentration.

から硝酸イオン濃度が同程度である $20^{\circ} \mathrm{C}$ 区と $22^{\circ} \mathrm{C}$ 区を比較 すると, 乾物率が大きくなる $20^{\circ} \mathrm{C}$ 区の方が $22^{\circ} \mathrm{C}$ 区に比べて優 れていると考えられる.

根から吸収され，硝酸トランスポーターによって細胞内へ と取り达まれた硝酸イオンは亜硝酸イオンを経てアンモニアへ と還元される. この反応は細胞質で機能する硝酸還元酵素 (NR) と葉緑体内で機能する亜硝酸還元酵素 $(\mathrm{NiR})$ によっ て行われる. 光合成で生成した化学エネルギーは NADH と して細胞質に運ばれ，NRの還元力として働く ${ }^{14)}$. 通常, 多 量の亜硝酸イオンは植物細胞にとって有害であるので, 還元 力が不足し反応が円滑に進まない場合は, NR の活性を調整 し, 余剩な硝酸イオンは液胞内に貯蔵される.つまり, 硝酸イ オン濃度を低減化させるためには, NR の活性化が鍵となる。 $\mathrm{NR}$ 活性の制御機構はいまだ解明されていないが, 光環境と

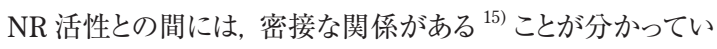
る.

明所下ではNR はリン酸化を受けておうず活性型である. 一方, 暗所下ではNR はリン酸化の影響を受け, NR 阻害夕 ンパク質と結合し不活性型となる. 光による NR の誘導や活 性化は, 窒素の同化が光合成と密接に結びついているという ことを示す. 硝酸の還元に必要な還元力は光合成のエネル ギーに由来し, アンモニアがグルタミン酸へと同化されるには 光合成に由来する炭素骨格 ( $\alpha$ - ケトグルタル酸) が必要で ある. 炭素同化系が窒素同化に影響を与えるように, 窒素同 化も炭素代謝に対して影響を与える. 硝酸イオンが窒素同化 系を誘導するシグナルとして働くと同時に, 炭素の代謝を制御 するシグナルとして働く ${ }^{15)}$.つまり, 炭素代謝が促進されると, 窒素代謝も促進される, まさに車の両輪の如く進行している.

乾物率が高くなるということは炭素同化が活発であるといえ る. また硝酸イオン濃度が低いということは窒素代謝が活発で あるといえる. Table 13, Fig. 11 より乾物率と硝酸イオン濃度 との間に相関が見られた. 炭素代謝と窒素代謝の活性化は 互いに関係し合うことが示された結果となった. 両代謝共に
光反応に大きく依存する反応である. よって乾物率を高める, すなわち炭素固定を活性化させる光質環境が硝酸イオン濃 度を低減させる環境であると考兄れる。

\section{3. 光質が硝酸イオン濃度, 乾物率に与える影響}

$\mathrm{R} / \mathrm{B}$ 比 20 区, 10 区, 5 区は植物生体重増加を促す傾向 がみられた. 乾物率では R/B 比 10 区, 5 区, 1 区で高い值 を示した. 硝酸イオン濃度では R/B 比 10 区, 5 区, 1 区で 低い值を示した (Table 5 および Table 9). 乾物率が高い值 を示した光質では硝酸イオン濃度值も低い值を示した. 前述 の乾物率と硝酸イオン濃度との相関を示す結果である. また 炭素固定が行われるほど乾物重は大きくなり生体重も大きくな るといえる. 従って生体重を大きくする光質は乾物率を高く, かつ硝酸イオン濃度を低くすると考えられる.

一般に青色光は植物の葉や茎の伸長生育を強く抑制する とされるが ${ }^{16)}$, 本研究においても青色光を含まない $\mathrm{R} / \mathrm{B}$ 比 の区では激しい徒長が見られた. しかし青色光のみで育成し た R/B 比 0 区でも徒長がみられた (Fig. 5). 青色光のみで は光合成速度が低くなるため生育が順調に行われなかったと 考えられる. 森らは成長率は単色光よりも赤色と青色の組合 せの方が大きくなったことを示した ${ }^{7)}$. 今回の実験結果では赤 色のみの $\mathrm{R} / \mathrm{B}$ 比 $\infty$ 区や青色のみの $\mathrm{R} / \mathrm{B}$ 比 0 区では生体重 増加量が小さく硝酸イオン濃度も著しく高い值を示した. この ことから単色光は植物成長にも硝酸イオン濃度の低減にも適 さないといえる.

$\mathrm{R} / \mathrm{B}$ 比 1 区は乾物率が高く, また硝酸イオン濃度を低減し た. しかし生体重増加量は $\mathrm{R} / \mathrm{B}$ 比 10 区, R/B 比 5 区に劣 る結果となった. $\mathrm{R} / \mathrm{B}$ 比 10 区, $\mathrm{R} / \mathrm{B}$ 比 5 区は $\mathrm{R} / \mathrm{B}$ 比 1 区 と比較して乾物率は小さく, 硝酸イオン濃度は高い結果であ った. 分散分析の結果からはこれら R/B 比 3 試験区間で 生体重増加量と乾物率に有意差は認められなかった. 植物 育成用光源の評価として光源の光合成有効波長域の比エネ ルギの光合成作用曲線 (スペクトル) との比較があり, 光合 成作用曲線の $\mathrm{R} / \mathrm{B}$ 比は光量子束密度換算で 2.9 の值を示 す ${ }^{17)}$. このことから R/B 比 1 区は効率の良い光合成を促し, 乾物率を高め, 硝酸イオン濃度を低減する結果となったと考え られる.

硝酸イオンの還元に硝酸還元酵素 NR が大きく関係してい ることは前述の通りである. 今回の実験で実施した試験区に

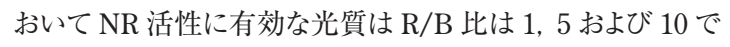
あるといえる. 乾物率を成長の指標とするならば R/B 比 1,5 および 10 が成長に適しているといえる。

\section{摘 要}

赤色光と青色光との光量子束密度比である $\mathrm{R} / \mathrm{B}$ 比を 0 , 
$1,5,10,20$ および $\infty$ (赤色光 $100 \%$ ) の 6 試験区設け栽 培実験を行った. 併せて室温を $20^{\circ} \mathrm{C}, 22^{\circ} \mathrm{C}, 25^{\circ} \mathrm{C}$ の 3 区設定 した. また $22^{\circ} \mathrm{C}$ 区においては栽培期間を $1,2,3$ 週間の 3 区 設定した. 以上により栽培温度, 栽培期間により光質がレタス 生体重, 乾物重および野菜中硝酸イオン濃度に与える影響を 解析した. その結果乾物率が高ければ硝酸イオン濃度が低 濃度となる相関関係が示され $\mathrm{R} / \mathrm{B}$ 比 $1,5,10$ が硝酸イオン 濃度低減に最も適していることが明らかとなった. 室温につい ては生体重増加量および硝酸イオン濃度で $20^{\circ} \mathrm{C}$ 区と $22^{\circ} \mathrm{C}$ 区 との間に有意差はなかったが, 乾物率では $20^{\circ} \mathrm{C}$ 区の方が有 意に大きくなった. このことからこの栽培システムでは $20^{\circ} \mathrm{C} 区$ が適していることが明らかになった。

\section{謝辞}

この研究は文部省科学研究費, 基盤研究 B (2) ( 課題番 号 17380155) の助成を受けた. 記して謝意を表する.

\section{引用文献}

1) 孫 尚穆, 米山忠克. 野菜の硝酸: 作物体の硝酸の生 理, 集積, 人の摂取. In : 公開シンポジウム講演資料, 日本学術会議土袞・肥料・植物栄養学研究連絡委員 会. 53-56. 1998.

2) 厚生労働省. 食品衛生調査会. 毒性添加物合同調 查. 食品添加物一日摂取量総点検調査報告. http : //www.ffcr.or.jp/zaidan/MHWinfo.nsf/98a5d7b 766af9bfb492565a10020c601/ce7101d177b43f054925 69df000ba6e6? OpenDocument. 2000.

3）渡辺博之. LED 光源の植物工場への適用. In : 日本植 物工場学会 SHITA REPORT. 11:31-41. 1996.

4) 森岡美帆. 発行パターン制御型 LED 照明装置とその 応用. In : 日本植物工場学会 SHITA REPORT. 18: 80-88. 2002.
5）渡辺博之. LED を光源とした野菜工場. In : 日本植物 工場学会 SHITA REPORT. 17：13-22. 2001.

6) 高辻正基, 辻 貴之, 関 義範, 星 岳彦. 可視発 光ダイオードによる植物栽培実験. 植物工場学会誌. $7(3)$ : 163-165. 1995.

7）森 康裕, 高辻正基. LED と LD 光がサラダナ成育に 及ぼす影響. 植物工場学会誌. 11(1)：46-49. 1999.

8）富士原和宏, 木村好克, 蔵田憲次. 赤. 青色 LED 弱 光照射低温貯蔵における青色光 PPFD 比率がトマト接 ぎ木セル成型苗の品質に及ぼす影響. 生物環境調節 学会誌. 41(4) : 361-368. 2003.

9) 大橋敬子, 富士原和宏, 木村好克, 松田 怜, 蔵田憲 次. 赤青色 LED 混合弱光照射が低温貯蔵中のトマト 接ぎ木セル成型苗の成長, Ribulose-1. 5-bisphosphate Carboxylase/Oxygenase 量, クロロフィル量および炭水 化物量に及ぼす影響. 生物環境調節学会誌. 42(1): 65-73. 2004.

10) Ohashi-Kaneko K, Fujiwara K, Kimuara Y, Kurata K. Effect of Blue-Light PPFD Percentage in Red and Blue LED Low-Light Irradiation during Storage on the Contents of Chlorophyll and Rubisco in Grafted Tomato Plug Seedling. Environ. Control Biol. 44(4) : 309-314. 2006.

11) 平井正良, 雨木若慶, 渡邊博之. LED による単色光照 射がナス, リーフレタス, ヒマワリの節間伸長に及ぼす影 響. 植物環境工学会誌. 18(2): 160-166. 2006.

12) 石村貞夫. 分散分析のはなし. 東京図書, 東京. 37-161. 1992.

13) 白旗慎吾. パソコン統計解析ハンドブックIVハンパラメトリ ック編. 共立出版, 東京. 1-173. 1987.

14）幸田泰則, 桃木芳枝. 植物生理学一分子から固体へ. 三共出版, 東京. 80-85. 2003.

15) 山谷知行. 朝倉植物生理学講座 2 代謝. 朝倉書店, 東京. 47-52. 2001.

16) 寺島一郎. 朝倉植物生理学講座 5 環境応答. 朝倉書 店, 東京 50-51. 2001.

17）高辻正基. 植物工場ハンドブック. 東海大学出版会, 東 京. 36. 1997. 